\title{
Role of Motivation, Creativity, Affective and Implications in the Teaching and Learning Process of Physical Education
}

\author{
Zulbahri*, Nugroho Susanto, Dessi Novita Sari \\ Physical Education \\ Faculty of Sport Science \\ University of Padang \\ E-mail: zulbahri@fik.unp.ac.id
}

\begin{abstract}
This research aims to describe the theory and practice as well as the implication of motivation, creativity and affective and their implications in the process of teaching and learning, The method used is a descriptive analysis of some works of literature. The results showed that the teachers had a tremendous influence on the direction of development of education in Indonesia. It explains teachers as professional educators rather than as a person who do the job of teaching. Students will be encouraged to learn when they are motivated, creative, and improved affective aspects of learning.
\end{abstract}

Keywords - Motivation, Creativity, Affective.

\section{INTRODUCTION}

Education is a long-term investment that is essential for a human being. Successful education will create appropriate human in society and not bothersome to others. Society of the least developed to the most advanced recognizes education or teacher is one among the many elements forming the main candidate for the main members of society. Successful education will create appropriate human and berkelayakan in society that becomes important is education to print the man who has the high quality and competitiveness. Educator or teacher can be likened to a travel counselor, which is based on knowledge and experience responsible for the smooth journey of learners in the learning process.

PJOK in the learning process, the learners of course there are some things that affect such as motivation, maturity, relationship with teachers learners, verbal ability, safety and teachers' skills in communicating or interacting with the student teacher is an important factor in the learning process. Where in the learning process in humans can be formulated as a mental or psychic activity that takes place in an active interaction with the environment, which resulted in changes in knowledge and attitude score. That change is relatively constant and scar. Mendai teacher so important in the learning process of learners in trying to realize a change in attitude and behavior.

However, in reality extrinsic motivation is what happens a lot, especially in children and adolescents in the learning process. The learning process will be successful when students are motivated to learn. Therefore, teachers should foster students' motivation. To obtain the optimum learning, creative teachers are required to encourage motivation, creativity and affective aspects of student learning.Other than that, PJOK for learning to grow and better yet, the need for maximum development with the support of various elements of achievement. "The availability of quality human resources who have excellent physical, mental and social conditions and mastery of science and technology are indicators of the success of a nation's development" [1].

\section{DISCUSSION}

\section{A. Motivations and Implications Role In Learning}

Students' learning motivation is not as strong, there are students whose motivation is intrinsic wherein the willingness of learning more robust and not dependent on factors outside himself. "In contrast with the students learning motivation is extrinsic, willingness to learn depends on conditions outside himself" [2]. The word motivation comes from the Latin word movere yai-tu, which means move (move). Motivation explain what makes people do things, make them stay practice, and assist them in phonlesaikan tasks. "This means that the concept of motivation is used to describe a desire to behave, behavioral direction (option), in-tensitas behavior (effort, continuous), and end or actual achievemen" [3].

1. Understanding Motivation

Defined as the power of motivation, encouragement, needs, encouragement, pressure, or psychological mechanisms that encourage a person or group of people to achieve specific achievements in line with what he wanted. Put forward the notion of motivation is an impulse that will cause a person to perform an act in order to achieve certain goals. Motivation is a condition or an internal status (sometimes interpreted as the needs, wants, or desires) that directs the behavior of people to actively act in order to achieve a goal. "Suggests that motivation is a process, which is internal or external to an individual, causing enthusiasm and persistence, in terms of carrying out certain activities" [2].

2. Indicators of Student Motivation 
determine the strength of students' motivation, it can be seen from some of the following indicators:
a) The strong will to do.
b) The amount of time available for study.
c) Willingness leave atautugas other liabilities
d) Persistence in doing the task [4].

Meanwhile, according Sardiman motivation to learn has the following indicators:
a) Persevering face the task.
b) Ductile face difficulties (not quickly despair)
c) Showed interest in various issues orangn adults.
d) More senag work independently
e) Quickly bored with routine tasks
f) Can hold his [5].

\section{Efforts to Improve Learning Motivation}

"Efforts to improve children's learning motivation in learning activities in schools, there are some steps that can be done by teachers expressed Sardiman namely:

a) Giving the figures in this regard as a symbol of the value of learning activities.

b) Rewards can be a powerful motivation, where students interested in a particular field to be awarded the prize.

c) Competition is competition, whether individuals or groups, it can be a means to increase the motivation to learn.

d) Ego-involvement raising awareness to the students to feel the importance of the task and accept it as a challenge to work hard is as a form of motivation that is quite important.

e) Giving replicates the students will study hard knowing that will be held replications.

f) Knowing the results Knowing learning outcomes can be used as a motivational tool.

g) Compliments If there are students who successfully complete the task properly, it should be given praise.

h) Punishment Punishment is a form of negative reinforcement, but if given correctly and wisely, can be a motivational tool" [5].

\section{Functions Motivation}

There are three functions of motivation, namely:

a) Encourage men to do. The motivation in this case is the motor of any activity to be undertaken.

b) Guided directions deed, ie towards the objectives to be achieved, thus the motivation to give directions, and activities that must be done in accordance with the formulation of objectives.

c) Selecting deeds, deeds that determine what should be done to match in order to achieve the goals, by setting aside the deeds that are not useful for that purpose.

\section{B. Role of Creativity and Learning Implications In PJOK}

1. Role of Student Creativity

That creativity is an ability that marks cir traits of creative people. More Guilford suggests two ways of thinking, namely the convergent and divergent thinking. Creativity is the ability to reflect fluency, flexibility and originality in thinking, as well as the ability to collaborate an idea. Further explained that creativity as a whole personality is the result of interaction with the environment.

\section{Characteristics of Creative Attitudes}

Suggests several characteristics of creative attitudes, such as: (a) have the self-confidence; (b) open to new experiences and outstanding; (c) flexible in thinking and acting; (d) be free in expressing themselves; (e) appreciation of fantasy; (f) an interest in creative activities; and (g) believe in their own ideas and independent [6].

a) Learning process

Learning is an effort to create the conditions to provoke learning objectives can be facilitated (facilitated) achievement. "The learning objectives must be "behavioral" or a form of behavior that can be observed, and "measurable" or can be measured" [7].

b) Learning objectives

Specifically includes the following learning objectives.

1) To assess learning outcomes. Teaching is considered successful if students achieve a predetermined goal. Achievement of the objectives by the students an indicator of success of the learning system.

2) To guide students to learn. The objectives were formulated precisely berdayaguna as a reference, directives, guidelines for students in learning activities.

3) To design a learning system. Itumenjadi basic objectives and criteria in an effort to teachers choose the subject matter, determine the teaching and learning activities, choose tools and resources as well as designing the assessment procedure.

4) To communicate with other teachers to improve the learning process.

c) In the Student Creativity Development Learning Process

In order to develop students' creativity, factors conducive learning environment is a crucial factor in whether students were able to give birth to a special creative achievements in the field of science. That is, to develop the creativity of students in learning, a teacher must have the skills, skills, and motivation creating a conducive learning suana.

\section{Affective and Implications Role In Learning PJOK \\ 1. Understanding Affective}

The affective aspect is related to the realm of attitudes and values. Affective includes character behaviors such as feelings, interests, attitudes, emotions, and values. Says that a person's attitude can be foreseen amendments when someone has had a high-level cognitive powers. The characteristics of affective learning results will appear on the learner in a variety of behaviors. Such as: his attention to the subject of Islamic religious education, discipline in following religious subjects in schools, the motivation high to know more about Islamic instruction that the receipt, 
appreciation or respect for Islamic religious education teachers and so on.

2. Affective Sphere Levels

"The affective sphere has five levels or tiers, namely:

a) Receiving or attending (Receiving or paying attention), Is the sensitivity of a person to receive a stimulus (stimulus) from outside who come to him in the form of problems, situations, and other symptoms. Included in this level for example is: awareness and willingness to accept the stimulus, control and selecting the symptoms or stimuli that come from the outside.

b) responding(Respond) implies "active participation". So the ability to respond to is the ability of a person to include themselves actively in certain phenomena and make a reaction to it one way.

c) valuing(Judge / appreciate). Assess or appreciate the means to give or pay tribute to an activity or an object, so that if the activity was not done, it is felt will bring loss or regret.

d) Organization (Arrange or organize), meaning memperdiscover the difference value to form a new universal values, leading to a general improvement.

e) Characterization by evalue or calue complex(Characterization by a value or complex values), the integration of all system values that have been owned by someone, which affects personality and behavior patterns. Here the process of internalization has occupied the highest place go-between a hierarchy of values. That value has consistently embedded in the system and has affected his emotions. This is the highest effective level, because the inner attitude of the students have been really wise" [5].

3. Characteristics of Affective

Characteristics affective attitude can be described as follows:

a) Curiosity is (1) always encouraged to find out more, (2)

ask a lot of questions, (3) always pay attention to people, objects and situations, (4) sensitive observation and would like to know / researching.

b) Imaginative, namely (1) able to demonstrate or imagine things that never happened, (2) use of fantasy and reality.

c) Feel challenged by the progress that is (1) driven to overcome a difficult problem, (2) are challenged by complex situations, (3) more interested in tasks difficult.

d) The nature of risk-taking, namely (1) dared to give an answer though not necessarily true, (2) do not be afraid of failure or criticism, (3) is not in doubt because of uncertainty, things that are unconventional, or less structured.

e) Appreciate nature, namely (1) can appreciate the guidance and direction in life, (2) appreciate the abilities and talents of its own thriving.

\section{CONCLUSION \\ 1. Implications Motivation in Learning}

Teachers often assume that student motivation is a problem the students themselves and it was students who are responsible for it that have high motivation. But actually the teacher may seek to establish the principles of motivation in the process and how to teach, to stimulate, increase and maintain the motivation of students to learn.

2. Implications Creativity in Learning

The creativity of students needs to be improved by the teacher to the learning outcomes of students can ditngkatkan. For it's not just students who need to be creative but also to be more creative teachers to enhance students' creativity. Teachers must have a curiosity to the maximum, the teacher must be willing to work hard, brave, intellectual skills utilized as much as possible, independent, dynamic, full of innovations / ideas and creativity, willing to receive information, connecting ideas and experience gained from various sources different, tend menampilkanberbagai alternatives to a particular subject.

3. Affective Implications in Learning

In the process of learning, the teacher is important to foster and develop affective

of each student. It is intended to foster student motivation in learning. Afek is also an important factor after students complete an activity. They of course will react emotionally to their successes and failures. "They are more tends to feel elated with success if they had not expected before and will experience negative emotions more deeply because of the failure" [2].

\section{REFERENCES}

[1] Z. Zulbahri, "Tingkat Kemampuan Daya Tahan Jantung dan Pernafasan Mahasiswa Pendidikan Olahraga dan Kesehatan Universitas Pasir Pengaraian", Gelanggang Olahraga: Jurnal Pendidikan Jasmani dan Olahraga, vol. 3, no. 1, pp. 96-101, Oct. 2019.

[2] S. Siti. "Upaya Guru Dalam Meningkatkan Motivasi Belajar Siswa.Jurnal Promosi”. Jurnal Pendidikan Ekonomi UM Metro, . vol. 3, no.1, pp 73-82, May. 2015.

[3] Zulbahri, Zulbahri. "PENINGKATAN KEMAMPUAN DAYATAHAN AEROBIK DENGAN METODE LATIHAN KONTINYU ATLET BOLAVOLI KABUPATEN ROKAN HULU." In Prosiding Seminar Nasional Teknopreneur Universitas Pasir Pengaraian, vol. 1, no. 1, pp. 672-675. July. 2018.

[4] J.W. Santrock. "Psikologi Pendidikan, Alih Bahasa Tri Wibowo B.S.” Jakarta: Kencana, 2008, pp. 34.

[5] E.R. Slavin. "Educational Psychology Theory and Practice, Eighth Edition" New York: Pearson Education, Inc. 2006, pp 43.

[6] J. Anidar. "Motivasi, Kreativitas Dan Implikasinya Dalam Pembelajaran Di Sd/Mi”. Jurnal Tarbiyah al-Awlad, vol 4, no. 2, pp. 445-452. July. 2011

[7] S. Sudarsono dan Eveline. "Media Pembelajaran Sebagai Pilihan Dalam Strategi Pembelajaran”. Jakarta: Universita Negeri Jakarta. 2004, pp 22. 